\title{
Saflufenacil Dose-Response Curves Applied to Brazilian 'Cerrado' Soils
}

\author{
Fernando Rezende Corrêa ${ }^{1,2}$, Virgínia Damin ${ }^{3}$, Alberto Leão de Lemos Barroso ${ }^{4,5}$, Hugo de Almeida Dan ${ }^{4,5}$ \\ \& José Arnaldo de Sousa Junior ${ }^{5}$ \\ ${ }^{1}$ School of Agronomy, Instituto Federal Goiano, Câmpus Rio Verde, Rio Verde, Brazil \\ ${ }^{2}$ School of Agronomy, Instituto de Ensino Superior de Rio Verde, Rio Verde, Brazil \\ ${ }^{3}$ Soil Science Department, Universidade Federal de Goiás, Goiânia, Brazil \\ ${ }^{4}$ School of Agronomy, Universidade de Rio Verde, Rio Verde, Brazil \\ ${ }^{5}$ Grupo de Pesquisa em Plantas Daninhas no Cerrado, Rio Verde, Brazil \\ Correspondence: Fernando Rezende Corrêa, Instituto de Ensino Superior de Rio Verde (IESRiver), Rua Doze de \\ Outubro, 42, 75906577, Jardim Adriana, Rio Verde, Goiás, Brazil. Tel: 55-64-9-9642-8627. E-mail: \\ fernandorvcorrea@gmail.com
}

Received: December 19, 2018

Accepted: January 27, 2019 Online Published: March 15, 2019

doi:10.5539/jas.v11n4p349

URL: https://doi.org/10.5539/jas.v11n4p349

\begin{abstract}
The objective of this study was to evaluate the phytotoxicity of saflufenacil in Brazilian Cerrado soils with contrasting properties. Experiments were performed in a factorial design. To quantify herbicide phytotoxicity, the bioassay technique was used and cucumber (Cucumis sativum) was selected as a test plant. A greater reduction of the dry mass was observed for bioindicator plants in comparison to others in the Typic Dystrophic Red Latosol. A rate of 11.76 g i.a. ha ${ }^{-1}$ was required to reach $50 \%$ reduction of the plant dry mass for this soil. Rates of 30.87 ; 44.10 , and 119.56 g i.a. ha ${ }^{-1}$, respectively, are needed to achieve a $50 \%$ reduction of the plant dry mass in the Typic Acric Red Latosol, Typical Orthic Arenosols Quartzipsamment, and Washed Sand. The bioavailability of saflufenacil is affected by soil properties and therefore the soil type should be considered when deciding upon possible rates.
\end{abstract}

Keywords: chemical control, sorption, cerrado soil, Cucumis sativum

\section{Introduction}

The use of herbicides to control weeds in agricultural systems is of great relevance for large-scale agriculture (Monquero, 2014). However, due to the high potential for environmental impact, the rational use of these molecules has been desired. Especially for pre-emergent herbicides, one of the greatest difficulties in reducing the applied amounts of such molecules is due to the fact that their efficacy and environmental impact potential are related not only to the characteristics of the molecule, but also to edaphoclimatic conditions.

In tropical soils, organic matter $(\mathrm{OM})$ has been considered the main component to influence herbicide activity in the soil (Mallawatantri \& Mulla, 1992). In addition to the importance of OM to increase soil cation exchange capacity (CEC), the sorption of herbicides with high hydrophobicity is greatly affected by the organic fraction. Several authors have observed that the bioactivity of these herbicides was inversely related to the OM content and directly related to the $\mathrm{pH}$ of the soil (Anderson, 1985; Gray et al., 1997; Jorgensen \& Hamner, 1948; Kerr et al., 2004; Weber et al., 1974).

Although OM is very important for pesticide retention, the type of filler present in soil clay minerals should also be considered. Prata et al. (2003) observed increased sorption of glyphosate in soils with high levels of oxides. The authors also verified that OM played a secondary role in the herbicide sorption. Acidic herbicides, such as glyphosate and saflufenacil, present a negative charge when in the ionic form and a positive charge on the surface of iron and aluminum oxides and hydroxides, abundant minerals in the highly weathered Oxisols of the Cerrado (Embrapa, 2013).

Saflufenacil is a selective contact herbicide of the chemical group pyrimidinedione (uracil) (NCBI, 2017). The ionization constant of the molecule (pKa) is 4.41 , thus it is considered moderately acidic. Its solubility in water is 
$30 \mathrm{mg} \mathrm{L}^{-1}$ at $\mathrm{pH} 5.0$ and $2.100 \mathrm{mg} \mathrm{L}^{-1}$ at $\mathrm{pH} 7.0$, and vapor pressure is $2.010^{-14} \mathrm{~Pa}$ at $25^{\circ} \mathrm{C}$. This herbicide inhibits the protoporphyrinogen oxidase enzyme (PROTOX). Such enzyme is found in the chloroplasts and mitochondria of plant cells and is the last common one for the production routes of chlorophyll synthesis and heme compounds (Monquero, 2014). After absorption by the plant cells, saflufenacil causes the accumulation of compounds that interact with light and oxygen, consequently producing highly reactive oxygen species (ROS), leading to membrane rupture and cell death (Hess, 2000).

Due to the lack of information about the behavior of saflufenacil in soils of the Cerrado biome and the importance of this biome for the Brazilian agricultural production, the objective of this study was to evaluate the bioavailability of this herbicide in Brazilian Cerrado soils.

\section{Materials and Methodology}

The experiment was performed in greenhouse from April to May 2016. Soil samples (Typic Dystrophic Red Latosol (OXISOL) [LVd], Typic Acric Red Latosol (OXISOL) [LVw], and Typical Orthic Arenosols Quartzipsamment [RQo]) were obtained from areas with consolidated agriculture for more than ten years in the State of Goiás (Brazil). Also, washed sand was used as reference soil. Soil samples were withdrawn from the superficial horizon ( 0 to $0.20 \mathrm{~m}$ ) and their physicochemical properties were determined as described by Raij et al. (2001) and Moore and Reynolds (1989) (Table 1).

Table 1. Physicochemical properties of the soils used in the experiment. Rio Verde, Goiás, Brazil, 2016

\begin{tabular}{|c|c|c|c|c|c|c|c|c|}
\hline Soil & $\mathrm{pH}$ & OM & $\mathrm{P}$ & K & $\mathrm{Ca}$ & $\mathrm{Mg}$ & $\mathrm{Al}+\mathrm{H}$ & CEC \\
\hline & & $\mathrm{g} \mathrm{dm}^{-3}$ & $\mathrm{mg} \mathrm{dm}{ }^{-3}$ & ----- & - & $\mathrm{mol}_{\mathrm{c}}$ & - & ---- \\
\hline LVd & 4.6 & 23.0 & 23.7 & 0.37 & 1.8 & 1.0 & 3.3 & 6.49 \\
\hline LVw & 5.0 & 14.0 & 1.4 & 0.43 & 1.0 & 0.5 & 1.6 & 3.10 \\
\hline RQo & 4.4 & 14.0 & 13.2 & 0.43 & 1.8 & 1.0 & 2.2 & 5.49 \\
\hline \multirow[t]{2}{*}{ WS } & 5.8 & 3.0 & 7.4 & 0.04 & 0.3 & 0.2 & 0.7 & 1.25 \\
\hline & $\mathrm{V}$ & & Sand & & Silt & & Clay & \\
\hline LVd & 49.11 & 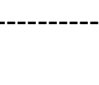 & 50 & & 10 & 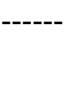 & 40 & \\
\hline $\mathrm{LVw}$ & 67.71 & & 48 & & 11 & & 41 & \\
\hline RQo & 59.86 & & 88 & & 4 & & 8 & \\
\hline \multirow[t]{2}{*}{ WS } & 43.89 & & 90 & & 3 & & 7 & \\
\hline & \multicolumn{8}{|c|}{ Mineralogical composition of the clay fraction } \\
\hline LVd & \multicolumn{8}{|c|}{ Gibbsite, kaolinite, and hydroxy interlayered vermiculite } \\
\hline $\mathrm{LVw}$ & \multicolumn{8}{|c|}{ Gibbsite, kaolinite } \\
\hline RQo & \multicolumn{8}{|c|}{ Gibbsite, kaolinite, and hydroxy interlayered vermiculite } \\
\hline WS & \multicolumn{8}{|c|}{ hydroxy interlayered vermiculite, chlorite, and talc } \\
\hline
\end{tabular}

Note. LVd: Typic Dystrophic Red Latosol (OXISOL); LVw: Typic Acric Red Latosol (OXISOL); RQo: Typical Orthic Arenosols Quartzipsamment; WS: Washed Sand; OM: Organic Matter; CEC: Cation Exchange Capacity in $\mathrm{pH} 7.0$; V: Saturation by Bases.

The design was completely randomized in a factorial scheme 4 ( 3 soil types + washed sand $[\mathrm{AL}]) \times 8$ (herbicide rates: $0 ; 12.25 ; 16.17 ; 24.5 ; 49 ; 98 ; 147$; and $196 \mathrm{~g} \mathrm{ha}^{-1}$ ) with 5 replicates. Each experimental unit corresponded to a vessel filled with $1 \mathrm{dm}^{3}$ of air-dried, sieved soil. Four cucumber seeds (Cucumis sativum) were sown per pot following the methodology used to evaluate herbicide bioavailability in the soil (Vivian et al., 2007). The cucumber was used as it was considered the bioindicator species with greater sensitivity to saflufenacil (Diesel et al., 2012).

The commercial product Heat ${ }^{\circledR}$ was the source of saflufenacil employed. Herbicide rates were applied 24 hours after sowing, using a $\mathrm{CO}_{2}$ pressurized backpack sprayer, with a spray bar containing six spaced nozzles $(0.50 \mathrm{~m})$, double fan type ADIA-110.02, under pressure of $2.0 \mathrm{Kgf} \mathrm{cm}^{-2}$, which gave the application a $150 \mathrm{~L} \mathrm{ha}^{-1}$ of spray volume. Throughout the experiment, moisture was maintained at $70 \%$ of the maximum soil water retention capacity (SWRC). To determine SWRC of each soil, $150 \mathrm{~g}$ of soil was weighed and placed in a beaker, to which $2 \mathrm{~mL}$ of distilled water was added in four replicates. After 60 seconds, the formed wet clod was removed, 
weighed and taken to the oven at $60{ }^{\circ} \mathrm{C}$ for 24 hours, and then weighed again. The percentage of field capacity for each soil was determined by the difference between the weights.

Saflufenacil toxicity on cucumber plants was evaluated at 7, 14, and 21 days after application (DAA) using a diagrammatic scale, according to the methodology described by SBCPD (1995), where zero corresponds to no plant injury and 100 corresponds to plant death. At 21 DAA, cucumber plants were cut close to the soil and the plant material was placed in a forced air circulation oven at $65^{\circ} \mathrm{C}$ for 72 hours to determine the dry mass of the aerial part (DMAP).

Data were submitted to analysis of variance. When the $\mathrm{F}$ test was significant $(\mathrm{P}<0.05)$, regressions were used to describe the behavior of quantitative factors. The log-logistic model proposed by Seefeldt et al. (1995) was used to calculate the rate that caused reduction of $50\left(\mathrm{GR}_{50}\right)$ and $80 \%\left(\mathrm{GR}_{80}\right)$ of plant growth (Christoffoleti \& López-Ovejero, 2004) in each soil. The results for the different soil types were compared by the Tukey test $(\mathrm{P}<$ $0.05)$.

\section{Results and Discussion}

Figure 1 shows the dose-response curves for saflufenacil in different soils as from the growth bioassay of cucumber plants. At 7 DAA, the lowest phytotoxic effect was observed for LVw, which differed from LVd at $24.5 \mathrm{~g}$ i.a. $\mathrm{ha}^{-1}$ and from the other soils as of $96.0 \mathrm{~g}$ i.a. ha ${ }^{-1}$. LVw are soils with large amounts of oxides in the clay fraction, which provide a high capacity to retain negatively charged compounds such as acidic herbicides in their ionized form. Saflufenacil, due to its pKa value (4.1), remains in the soil predominantly in the anionic form (Hixson, 2008). It was likewise the predominant form in all soils of the present work due to $\mathrm{pH}$ values (Table 1). Thus, a large amount of saflufenacil could be sorbed in the soils and would not be bioavailable to the cucumber plants.

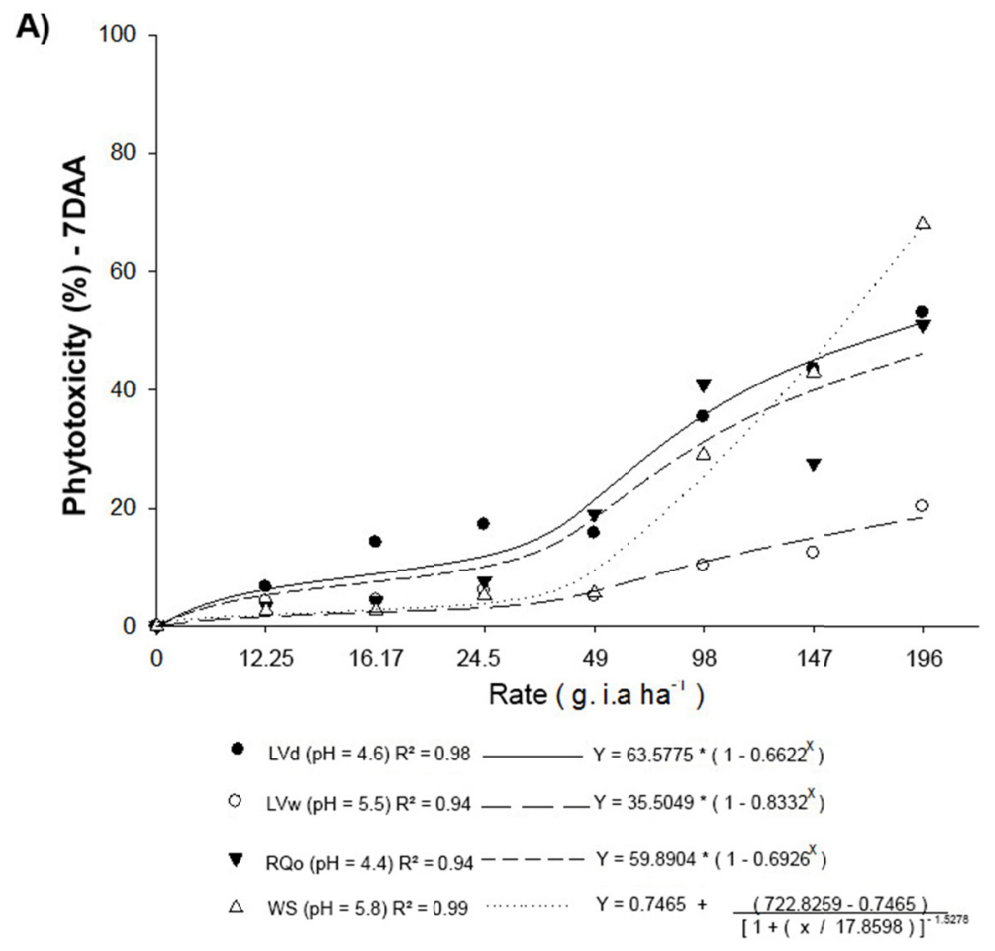



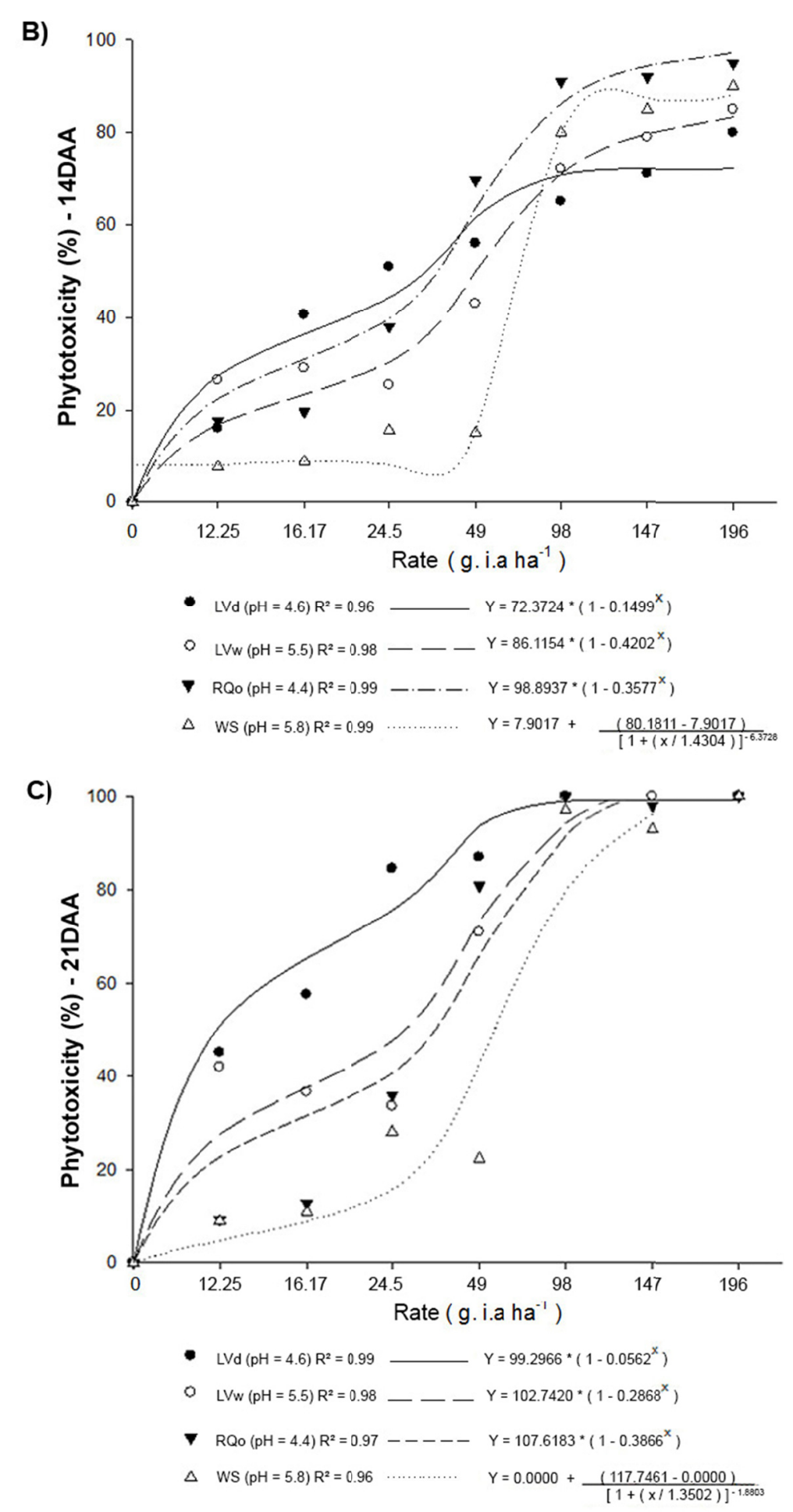

Figure 1. Toxicity effects in cucumber plants at different saflufenacil rates at 7 (A), 14 (B), and 21 (C) days after application (DAA). Rio Verde, Goiás, Brazil, 2016

At 14 and 21 DAA, the lowest phytotoxic effect was observed for WS until $49 \mathrm{~g}$ a.i. ha ${ }^{-1}$, possibly due to the sand low sorption capacity and high $\mathrm{pH}$ (Table 1), which favors herbicide leaching. As there was daily irrigation of the pots to maintain the SWRC at $70 \%$, the herbicide may have been leached, reducing its absorption by the roots. At high rates, however, saflufenacil showed higher phytotoxicity in WS and RQo than in LVd, suggesting increased availability of the safener, probably because the irrigation water was not sufficient to leach the herbicide, leaving it available in the layer. Sand and sandy soils have an elevated amount of macroporosity, 
conferring high hydraulic conductivity to the soil, which increases the herbicide leaching potential (Taiz \& Zeiger, 2004).
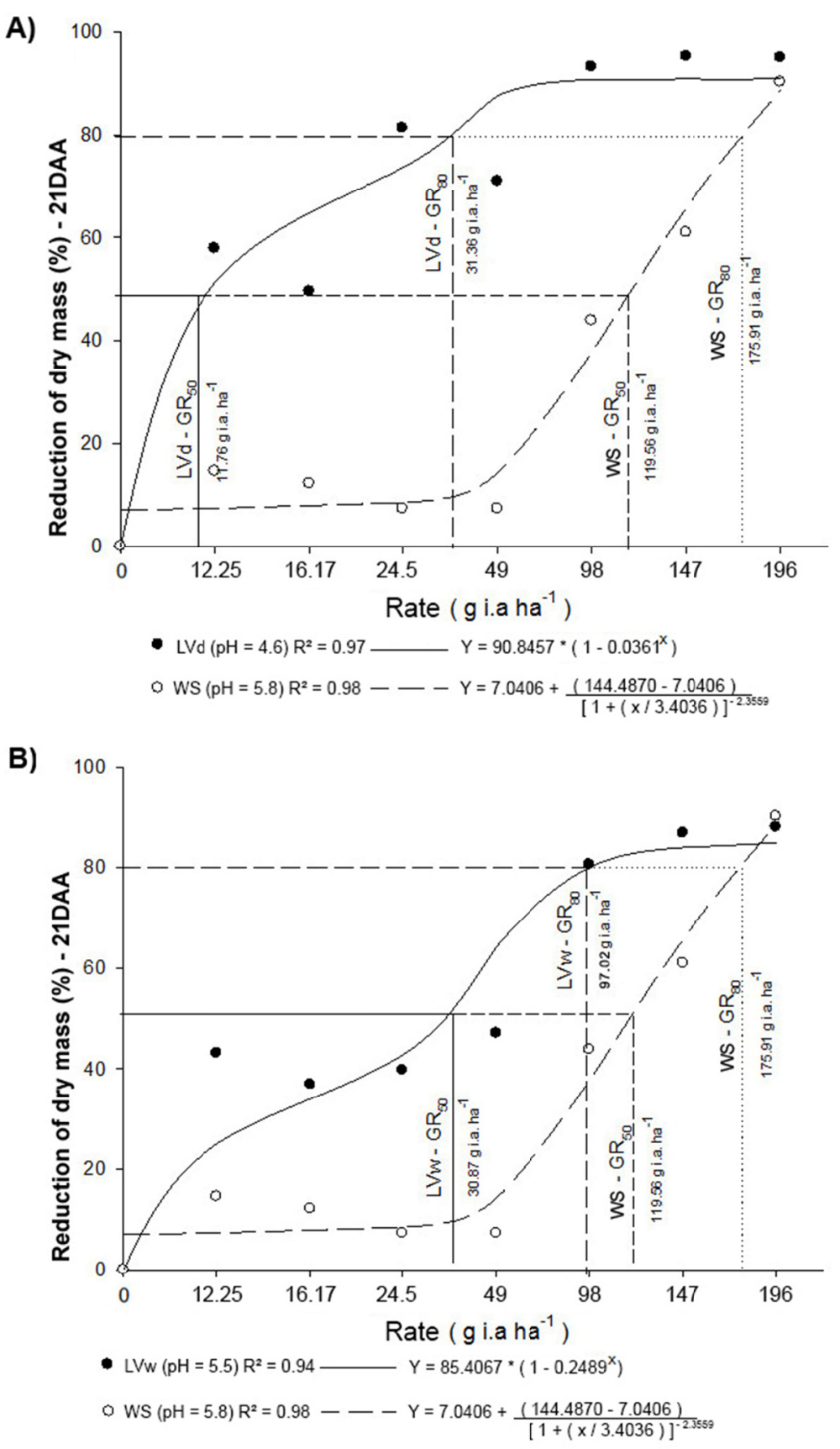


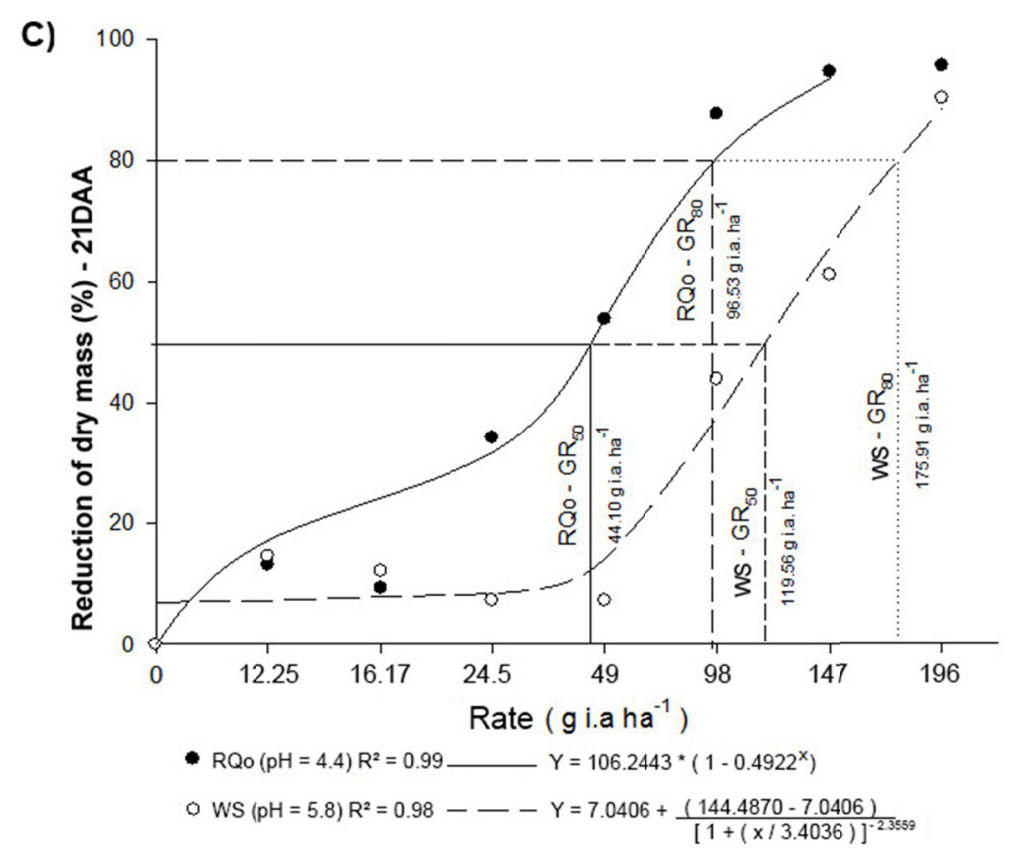

Figure 2. Dry mass of Cucumis sativum plants at 21 DAA for LVd (A), LVw (B), and RQo (C) soils compared to WS. Rio Verde, Goiás, Brazil, 2016

For the reduction percentage of DMAP, there was interaction of the evaluated factors. In both Latosols, the dry matter reduction was higher than in WS, except for rate 0 and the highest rate, at which there was no difference among treatments (Figure 2). The RQo differed from WS as of $24.5 \mathrm{~g}$ i.a. $\mathrm{ha}^{-1}$, and no differences were observed among treatments at the highest rate. Although RQo is similar to WS in terms of grain size composition, the very low OM contents associated with the presence of minerals that do not develop positive charge give WS a high potential for saflufenacil leaching. The soil RQo, although also quite sandy, contains higher levels of organic matter and clay when compared to WS, components that may favor the retention of the herbicide. Another important difference between RQo and WS that may have favored herbicide leaching in WS is pH 4.4 and 5.8 respectively. In AL, more than $90 \%$ of the molecules must be in the anionic form, since the $\mathrm{pH}$ value is higher than that of $\mathrm{pKa}+1$, whereas in RQo the $\mathrm{pH}$ value is very close to the pKa value of the product, if a little more than $50 \%$ of the molecules are in the ionic form. As saflufenacil develops a negative charge when ionized, and increasing soil $\mathrm{pH}$ results in elevated negative charges in the same, product loads are repelled by the soil. In a study of saflufenacil leaching, Monquero et al. (2012), working with the same soil, observed that the increase in the soil $\mathrm{pH}$ resulted in higher leaching of the herbicide.

Regarding the values of $\mathrm{GR}_{50}$, values of $11.8 ; 30.9 ; 44.10$; and $119.6 \mathrm{~g} \mathrm{ha}^{-1}$ were observed for $\mathrm{LVd}$, LVw, RQo, and WS, respectively. $\mathrm{GR}_{80}$ for these soils was, respectively, $31.4 ; 98.0 ; 96.5$; and $175.9 \mathrm{~g} \mathrm{ha}^{-1}$. Comparing GR values in Oxisols, larger $\mathrm{GR}_{50.80}$ was noticed for $\mathrm{LVw}$. As these soils have similar clay contents, the lower efficacy of the herbicide in LVw may be associated with a high amount of positive charges, which may reduce the availability of acidic herbicides (Prata et al., 2003).

\section{Conclusion}

The results of this research suggest that different soil properties, such as the $\mathrm{pH}$ value and the composition of the clay fraction, may affect the effectiveness of saflufenacil. Thus, soil properties should be considered before deciding upon saflufenacil rates. Studies under field conditions should be performed to better understand the behavior of this herbicide in Brazilian Cerrado soils.

\section{References}

Anderson, R. L. (1985). Environmental effects on metsulfuron and chlorsulfuron bioactivity in soil. Journal of Environmental Quality, 14, 517-520. https://doi.org/10.2134/jeq1985.00472425001400040011x

Christoffoleti, P. J., \& López-Ovejero, R. F. (2004). Definições e situação da resistência de plantas daninhas aos herbicidas no Brasil e no Mundo. In P. J. Christoffoleti (Ed.), Aspectos de resistência de plantas daninhas a 
herbicidas (2nd ed., pp. 3-22). Campinas: Associação Brasileira de Ação a Resistência de Plantas aos Herbicidas (HRAC-BR).

Diesel, F., Trezzi, M. M., Pazuch, D., Xavier, E., Rosin, D., \& Pagnoncelli, F. (2012). Seleção de espécies da família cucurbitaceae e chenopodiaceae para indicação da presença de saflufenacil no solo-Pesticidas. Revista de Ecotoxicologia e Meio Ambiente, 22, 35-42.

EMBRAPA. (2013). Sistema Brasileiro de Classificação de Solos (p. 353). Brasília, Brazil.

Grey, T. L., Walker, R. H., \& Hancock, H. G. (1997). Sulfentrazone adsorption and mobility as affected by soil and pH. Weed Science, 733-738.

Hess, F. D. (2000). Light-dependent herbicides: An overview. Weed Science, 48(2), 160-170. https://doi.org/ 10.1614/0043-1745(2000)048[0160:LDHAO]2.0.CO;2

Hixson, A. C. (2008). Soil properties affect simazine and saflufenacil fate, behavior, and performance (226 f., Tese (Doutorado), Faculty of North Caroline Satate University).

Jorgensen, C. J. C., \& Hamner, C. L. (1948). Weed control in soils with 2,4-Dichlorophenoxyacetic acid and related compounds and their residual effects under varying environmental conditions. Botanical Gazette, 109, 324-333. https://doi.org/10.1086/335483

Kerr, G. W., Stahlman, P. W., \& Dille, J. A. (2004). Soil pH and cation exchange capacity affects sunflower tolerance to sulfentrazone. Weed Technology, 18, 243-247. https://doi.org/10.1614/WT-03-025R

Mallawatantri, A. P., \& Mulla, D. J. (1992). Herbicide adsorption and organic carbon contents on adjacent low-input versus conventional farms. Journal Environmental Quality, 21(4), 546-551. https://doi.org/ $10.2134 / \mathrm{jeq} 1992.00472425002100040004 \mathrm{x}$

Monquero, P. A. (2014). Aspectos da biologia e manejo das plantas daninhas (p. 400). São Carlos: RIMA.

Monquero, P. A., Sabrag, R., Orzari, I., Hijano, N., Galvani Filho, M., Dallacosta, V., ... Hirata, A. C. (2012). Lixiviação de saflufenacil e residual após período de seca. Planta Daninha, 30(2), 415-423. https://doi.org/ $10.1590 / \mathrm{S} 0100-83582012000200022$

Moore, D. M., \& Reynolds, R. C. (1989). X-ray diffraction and the identification and analysis of clay minerals (p. 332). New York, Oxford University Press.

NCBI (National Center for Biotechnology Information). (2017). PucChem Compound Database, Compound Summary for CID 11571392 (Saflufenacil). Retrieved from https://pubchem.ncbi.nlm.nih.gov/compound/ 11571392

Prata, F., Cardinali, V. C. D. B., Lavorenti, A., Tornisielo, V. L., \& Regitano, J. B. (2003). Glyphosate sorption and desorption in soils with distinct phosphorus levels. Scientia Agricola, 60(1), 175-180. https://doi.org/ 10.1590/S0103-90162003000100026

Raij, B. van., Andrade, J. C., Cantarella, H., \& Quaggio, J. A. (2001). Análises químicas para avaliação da fertilidade de solos tropicais. Campinas, Instituto Agronômico.

Seefeldt, S. S., Jensen, S. E., \& Fuerst, E. P. (1995). Loglogistic analysis of herbicide dose-response relationship. Weed Technology, 9, 218-227. https://doi.org/10.1017/S0890037X00023253

SBCPD (Sociedade Brasileira da Ciência das Plantas Daninhas). (1995). Procedimentos para instalação, avaliação e análise de experimentos com herbicidas (p. 42). Londrina.

Taiz, L., \& Zeiger, E. (2004). Fisiologia Vegetal (3rd ed., p. 722). Porto Alegre: Artmed.

Vivian, R., Queiroz, M. E. L. R., Jakelaitis, A., Guimarães, A. A., Reis, M. R., Carneiro, P. M., \& Silva, A. A. (2007). Persistência e lixiviação de ametryn e trifloxysulfuron-sodium em solo cultivado com cana-de-açúcar. Planta Daninha, 25(1), 111-124. https://doi.org/10.1590/S0100-83582007000100012

Weber, J. B., Weed, S. B., \& Waldrep, T. W. (1974). Effect of soil constituents on herbicide activity in modified-soil field plots. Weed Science, 22, 454-459.

\section{Copyrights}

Copyright for this article is retained by the author(s), with first publication rights granted to the journal.

This is an open-access article distributed under the terms and conditions of the Creative Commons Attribution license (http://creativecommons.org/licenses/by/4.0/). 